Canadian Science Publishing

Canadian Journal of Earth Sciences Revue canadienne des sciences de la Terre

\title{
Soft-sediment deformation structures induced by rapid sedimentation in Early Cretaceous turbidites, Lingshan Island, eastern China
}

\begin{tabular}{|c|c|}
\hline Journal: & Canadian Journal of Earth Sciences \\
\hline Manuscript ID & cjes-2017-0106.R2 \\
\hline Manuscript Type: & Article \\
\hline Date Submitted by the Author: & 15-Sep-2017 \\
\hline Complete List of Authors: & $\begin{array}{l}\text { Liang, Zhao; School of Geosciences, China University of Petroleum (East } \\
\text { China), Department of Geology } \\
\text { Zhou, Yaoqi; School of Geosciences, China University of Petroleum (East } \\
\text { China), Department of Geology } \\
\text { van Loon, A.J.; Geocom Consultants, }\end{array}$ \\
\hline $\begin{array}{r}\text { Is the invited manuscript for } \\
\text { consideration in a Special } \\
\text { Issue? : }\end{array}$ & N/A \\
\hline Keyword: & $\begin{array}{l}\text { soft-sediment deformation structures, turbidites, dome structures, rip-up } \\
\text { clasts, Lingshan Island }\end{array}$ \\
\hline
\end{tabular}




\section{Soft-sediment deformation structures induced by rapid sedimentation in Early Cretaceous turbidites, Lingshan Island, eastern China}

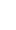

Zhao Liang, Yaoqi Zhou, and A.J. (Tom) van Loon

Zhao Liang. Department of Geology, School of Geosciences, China University of

Petroleum (East China), No. 66, Changjiang West Road, Huangdao District, Qingdao,

China. (zhaoliang19860119@hotmail.com)

Yaoqi Zhou. Department of Geology, School of Geosciences, China University of

Petroleum (East China), No. 66, Changjiang West Road, Huangdao District, Qingdao,

China. (zhouyq@upc.edu.cn)

A.J. (Tom) van Loon. Geocom Consultants, Valle del Portet 17, 03726 Benitachell,

Spain. (Geocom.VanLoon@gmail.com); College of Earth Science and Engineering,

Shandong University of Science and Technology, No.579, Qianwangang Road,

Huangdao District, Qingdao, China 266590

Corresponding author: Zhao Liang (email:zhaoliang19860119@hotmail.com). 
Abstract: Turbidites of the Early Cretaceous Lingshandao Formation on Lingshan Island, eastern China, show numerous soft-sediment deformation structures. The turbidites accumulated in a rift basin plain on the distal part of a low-energy fan, together with autochthonous fine-grained sediments that settled from suspension. Occasionally, sets of both types of sediments slumped down the basin slope. The turbidites were studied in two sections. Paleocurrent directions, measured from sole marks at the base of the sandy turbidites, indicate a slope from SE to NW; this is consistent with the dip direction of the axial planes of the major slump folds. Among the numerous types of soft-sediment deformation structures that are present, two types are of special interest because of their specific genesis, viz. rip-up clasts and dome structures. It appears that rapid sedimentation must be considered as the main trigger behind these deformations: the rapid accumulation of particularly the sandy turbidites resulted in overloading of the underlying beds and then consequently an increase in their pore-water pressure that induced liquefaction/fluidization, which triggered the formation of the rip-up clasts and dome structures. The downslope movement of freshly deposited turbidites after slope failure over the inclined sedimentary surface induced shear stresses, which resulted in the complication of the rip-up clasts and the preferred orientation of some dome structures. Both the dip directions of the axial planes of some of the dome structures and micro-folds within the rip-up clasts are consistent with the paleocurrent direction indicated by the sole marks and the slump folds.

Keywords: soft-sediment deformation structures; turbidites; dome structures; ripup clasts; Lingshan Island 


\section{Introduction}

Soft-sediment deformation structures (SSDS; this acronym is used in the present contribution for both singular and plural) include a wide range of sediment deformations with various morphologies; they are preserved in ancient and modern sediments all over the world, in all depositional environments (Allen and Banks 1972; Allen 1977; Owen 1987, 1996; Moretti 2000; Van Loon 2009; Owen et al. 2011). SSDS are of great significance in providing sedimentary records of processes acting on sediments while they were unconsolidated or semi-consolidated during or shortly after deposition (Owen 1987). A sudden decrease or the complete loss of shear strength due to deformation mechanisms in water-saturated sediments allow deformations to occur under the influence of driving-force systems. Sediments behave as viscous or liquid-like materials when they are deformed (Allen 1977; Owen 1987, 1996; Moretti and Ronchi 2011; Suter et al. 2011; Tinterri et al. 2016), thus resulting in deformation in the case of liquefaction and in complete loss of the primary structures in the case of fluidization.

Numerous types of soft-sediment deformation structures, including load structures, convolute lamination and water-escape structures, are commonly present in turbidites (Sanders 1956; Lowe 1975; Allen and Banks 1972; Stromberg and Bluck 1998; Moretti et al. 2001; Tinterri et al. 2016); most of them result from liquefaction and/or fluidization (Allen 1977) of water-saturated sediment after passing the failure threshold due to a rapidly thickened overburden resulting from a high sedimentation rate (Moretti et al. 2001).

During the Early Cretaceous, the area where Lingshan Island (offshore eastern Shandong Province, eastern China) is situated nowadays (Fig. 1) formed part of an inter-arc basin with a tensional tectonic regime (Yang and Van Loon 2016); it was 
67 thus affected by active tectonics. This resulted in relatively steep basin slopes and,

due to erosion of the hinterland, a vast supply of siliciclastic particles that led to rapid accumulation on the slopes. The combination of these factors favored slope failure and the initiation of turbidity currents, debris flows and hyperpycnal flows (Yang et al. 2016). Where these flows came to rest, the weight of the freshly deposited sediments increased the pore-water pressure of the underlying, still unlithified layers, resulting in liquefaction, sometimes followed by fluidization (cf. Allen 1977). Consequently, a wide variety of SSDS originated, due to the sometimes chaotic local stress fields that resulted from the combination of mass-flow activity, reversed density gradients, slope conditions, and liquefaction/fluidization; these SSDS provide insight into the depositional conditions (Yang et al 2016). The presence of tectonic activity (rifting, earthquakes) contributed to the instability of the sediments, thus also resulting in SSDS such as synsedimentary faults, boudins (including domino boudins), etc., which provide insight into the tectonic regime (Yang and Van Loon 2016). In addition to the more commonly occurring SSDS such as load casts, pseudonodules, waterescape structures, convolutions, etc., which have been described earlier (e.g. Lu et al 2011, 2012; Shao et al 2014), two types of SSDS are present that were not earlier described from the Lingshandao Formation, viz. dome structures and rip-up clasts. They are important because the dip directions of the axial planes of some of the dome structures and micro-folds in the rip-up clasts are related to the lateral shear stress that was probably induced by the flow of turbidity current (Moretti et al. 2001), thus indicating the direction of the basin slope. Moreover, the rip-up clasts were not the result of some erosional activity (like normally) but rather a result of a depositional process, and the dome structures are a type of SSDS that has not been detailed 
91

before, although some genetically related SSDS (e.g. flames, squeezed structures) have been dealt with previously by, among others, Olivaira et al. (2011).

Consequently we focus here on these two specific types of SSDS in the turbidite successions that are well-exposed in the Dengta section $(\sim 8 \mathrm{~m})$ and the Qiancengya section ( $20 \mathrm{~m})$ (both located in the sea cliffs in the southwest of Lingshan Island)

(Fig. 1). We discuss their deformation mechanisms, driving forces and trigger mechanism, with the objective to highlight the significance of rapid sedimentation for the formation of these specific types of SSDS.

\section{Geological setting}

The turbidite section under study crops out in coastal cliffs on Lingshan Island, an island in the Yellow Sea, about $40.7 \mathrm{~km}$ SE from Qingdao City, Shandong Province, eastern China (Fig. 1a). The island covers an area of about $8 \mathrm{~km}^{2}$ and its top is about $513.6 \mathrm{~m}$ above sea level.

Lingshan Island is located in the Lingshandao Depression (Fig. 1b-c) (Luan et al. 2010), between the Qianliyan High and the Jiaonan High (Wang 2013). The latter belongs to the Sulu Orogenic Belt that developed due to the collision of the North China Plate with the Yangtze Plate in the Triassic (Li 2009). The main faults trend NE-SW and control the spatial distribution of the various tectonic units; secondary faults trend NW-SE and divide the Lingshandao Depression and determine the dip of the sediments.

\section{Previous and latest hypotheses}

The complex structural setting and the geographically isolated position of the island caused an strong scientific debate about its precise geotectonic, stratigraphic and 
116

117

118

119

120

121

122

123

124

125

126

127

128

129

130

131

132

133

134

135

136

137

138

139

sedimentological setting (Faure et al., 2003; Wu et al., 2005; Lu et al., 2011, 2012;

Shao et al., 2014; Wang et al., 2014; He et al., 2015; Zhou et al., 2015). Recent research has made clear, however, that the Lingshandao Formation cannot, as previously assumed (SBGMR 1991), be correlated with the uppermost part of the contemporaneous Laiyang Group in the nearby Jiaolai Basin (Wang et al., 2014), but must rather be considered as a different entity. Based on trace-element analysis, it has also become clear that the formation accumulated in a deep-marine environment (Yang et al 2017), rather than in a continental environment as was assumed on the basis of the finds of carbonized plant debris (Zhong 2012); the plants were found by recent investigations to have been washed in by hyperpycnal flows (Yang et al 2016). Further, it was found on the basis of analysis of stress systems that can be deduced from SSDS such as domino boudins, that an overall tensional regime prevailed during sedimentation of the Lingshandao Fm., but that the resulting deformations caused local (fairly small-scale) compression, which is also expressed by specific soft-sediment deformation structures such as small synsedimentary upthrusts.

\section{Sedimentary and structural history}

Eastern China was part of the Circum-Pacific tectonic domain during the Early Cretaceous; it became affected by the fast subduction of the Pacific Plate. Distinct lithospheric thinning occurred during the Late Mesozoic (Wu et al. 2005). Magmatic intrusions and volcanic eruptions were particularly frequent and active during Early Cretaceous (Zhou et al. 2015). Rift basins developed in this extensional setting at both sides of the Sulu Orogenic Belt, including the large rift basin in the south that 
140 includes the Lingshandao Depression, and that nowadays trends NE-SW in the 141 offshore region of eastern Shandong (Zhou et al. 2015).

142 A thick deep-water succession mainly consisting of turbidites (the Lingshandao 143 Fm.) was deposited in the Early Cretaceous. Subsequently, the study area was uplifted and tilted, resulting in the overall ENE dip direction of the strata (Yang and Van Loon 2016). The ongoing regional tectonic uplift caused shallowing of the basin, leading to a change in facies from deep to shallow marine to a continental delta front (Shao et al. 2014). This was accompanied by intense magmatic activity, so that shallow-marine sediments alternate with volcanic material. Four stratigraphic units (Fig. 1d) are exposed in the coastal cliffs of Lingshan Island (Zhang et al. 2013). The oldest unit is composed of $\sim 90 \mathrm{~m}$ of greyish yellow thinbedded sandstones alternating with dark grey to black shales (Lu et al. 2011; Yang and Van Loon 2016) that correspond to the deep-marine succession accumulated during the Early Cretaceous. This succession constitutes the Lingshandao Formation (Zhang et al. 2013) (mainly comprising turbidites, with some debrites and hyperpycnites). The Lingshandao Formation (Zhang et al. 2013) is overlain by a regionally extensive layer of grayish white rhyolite belonging to the Bamudi Formation, which can be used as a marker bed for stratigraphic correlation. This rhyolite is, in andesites, which also belong to the Bamudi Formation (Zhou et al. 2015).

162 turn, overlain by shallow-water deltaic deposits intercalated by several layered diabase intrusions and pyroclastic flows, indicating gradual regional tectonic uplift and active volcanism. The uppermost unit is composed of volcanic agglomerates and

\section{Characteristics of the Lingshandao Fm.}


The turbidites of the Lingshandao Formation, which contain the SSDS that are the main subject of the present contribution, crop out mainly in the south and west of Lingshan Island, and are best accessible on the Dengta and Qiancengya sections (Fig. 1) where the present study was carried out. These sections consists mainly of turbidites, often in the form of beds grading from sandstone to siltstone to mudstone, but fine-grained turbidites form the majority. These fine-grained turbidites tend to show, just like the fine-grained upper parts of the coarse turbidites, millimeter-scale horizontal laminae. These fine-grained allochthonous sediments cannot be distinguished in the field from the autochthonous sediments that settled from suspension.

Groove casts and flute casts occur on the lower bedding planes of the sandstone turbidites (Fig. 2). Locally sets of turbidites were reworked in the form of slumps. These slumps differ in size and contain sometimes complex folds. The axial planes of the major folds in these slumps dip to $\mathrm{N} 120^{\circ}$, consistent with the paleocurrent direction measured from the sole marks mentioned above. Obviously, the complexand continuously changing - stress systems that exist in a slumping mass, have resulted in numerous smaller faults that show an almost complete spread in dip directions of the axial planes.

\section{The Dengta section}

The Dengta section (Fig. 3, upper right) consists of a vertical wall of about $8 \mathrm{~m}$ of turbidites (Fig. 3, left); a slump about $0.7 \mathrm{~m}$ thick is present at the base of the section (Fig. 3, lower right), and another slump about $2.5 \mathrm{~m}$ thick is present in the top part. The sandstones are of the order of a few millimeters to a few centimeters thick, but a few beds are over $10 \mathrm{~cm}$ thick. The basal parts of the turbidites tend to show normal 
grading, and to erode the fine-grained tops (mainly shales, occasionally mudstones with varying clay/silt ratios) of the underlying turbidites; the more fine-grained upper parts show millimeter-scale parallel lamination, commonly well distinguishable by different weathering colors.

\section{The Qiancengya section}

The Qiancengya section (Fig. 4) is about 20 m thick. It consists of grayish yellow sandstone layers and grayish black fine-grained sediments (Fig. 4, left). The sandstone turbidites are centimeters to decimeters thick (Fig. 4, lower right), and commonly show an erosional base and normal grading. The fine-grained parts of these coarse turbidites can also be some centimeters to some decimeters thick, and some of them display millimeter-scale parallel lamination.

\section{Depositional environment}

In both sections, the turbidite succession is built by sequences that show thickening- and coarsening-upward units. These sequences are similar to the "sandstone lobes" of meter-scale sandstone packages formed in the outer-fan settings described by Mutti and Ricci Lucchi (1978). Both the sandstone and the more fine-grained turbidites in the Dengta section are thinner than those in the Qiancengya section, possibly indicating deposition in a slightly more basinward (distal) setting.

Lingshan Island occupies an isolated place in the Yellow Sea, so that a clear sedimentological/paleogeographical context is lacking. However, the characteristics of the sediments in the Dengta and Qiancengya sections are diagnostic enough to deduce an outer-fan/basin-plain setting. The slumps in the Dengta section fit into this 
214 picture: Field et al. (1982) demonstrated that such slumps can be triggered by

215 seismic shocks that affect water-saturated sediments on slopes of even less than $1^{\circ}$

216 (cf. Berra et al. 2011). The slumped material consists of successions of turbidites and

217 autochthonous fine-grained sediments that moved downslope after failure of the

218 slope sediments, possibly under the influence of seismic shocks that resulted from

219 earthquakes in the tectonically active basin, although slope failure due to overloading

220 cannot be fully excluded. If seismic activity was responsible, the seismic shocks were

221 apparently not strong enough to initiate the formation of seismites (Yang and Van

222 Loon 2016), and earlier interpretations of SSDS as seismites (Wang 2013) must be

223 considered erroneous as the pertinent layer does not fulfill seismite criteria (Sims

224 1975; Obermeier 1996; Rossetti 1999; Wheeler 2002; Hilbert-Wolf et al. 2009; Owen

225 and Moretti 2011).

226

227 Description of the dome structures and rip-up clasts

228 Lu et al. (2011) were the first who described the turbidites of the Lingshandao

229 Formation and their SSDS. Several researchers studied these SSDS from then on,

230 and they all attributed them to seismic shocks (Wang 2013; Shao et al. 2014; Feng et

231 al. 2016; Yang and Van Loon 2016). None of these authors, however, described the

232 dome structures and rip-up clasts that are the main subject of the present

233 contribution, and which have - as we will detail further on - a different genesis.

\section{Dome structures}

The dome-shaped structures (called 'dome structures' in the following) occur in the

lower part of Dengta section. These deformation structures involve the fine-grained top parts of turbidites and the base of the overlying sandstone turbidite (Fig. 5). 
These dome-shaped structures are 1-5 cm wide and 1-3 cm high, showing a thickening of the bedding - which is well preserved - from their sides toward the central upper part of the structure. The sandstones surrounding the top of the 'domes' show normal grading; a remarkable feature is that some of the coarser grains have sunk into the sag of the underlying fine-grained sediment. Moreover, fragments of this underlying fine-grained sediment (actually millimeter-scale parallel-laminated sediments consisting most probably of both fine-grained turbidites and suspensionderived sediments) occasionally float in the overlying sandstone. Dark mud laminae in the overlying sandstone unit are penetrated by the dome structures. Minor flame structures occasionally develop from the flanks of the dome structures.

Several layers below the deformed level are also affected, as indicated by undulating bedding planes (Fig. 5c). These structures are irregular and the deformed level is laterally discontinuous. The irregular character of these deformed levels gradually disappears laterally within about $2 \mathrm{~m}$.

\section{The rip-up clasts}

A level with rip-up clasts (Fig. 6) is present in the Qiancengya section, at the base of the coastal cliff. These structures occur in a level between the upper, laminated fine-grained part of a sandstone turbidite and an overlying sandstone turbidite.

The laminated sediments that are involved have been broken up into fragments of different sizes; these fragments are strongly deformed. Part of the commonly angular fragments float in the sandstone part of the underlying turbidite, whereas other fragments float between laminae inside the fine-grained sediment, in the form of relatively thin clasts (Fig. 6a). Some of these thin fragments are also distorted, stretched and/or folded (Fig. 6b). 
Other specimens show laminae that have only been folded. The axial planes of these folds dip to the NNW (Fig. 6c). This direction is consistent with the paleocurrent direction indicated by the flute casts of the turbidites and by the dip of the axial planes of the major slump folds in the succession. Larger folds occur occasionally in some fragments (Fig. 6d).

\section{Interpretation of the dome structures and rip-up clasts}

Neither the dome structures nor this type of rip-up clasts have been interpreted previously. For this reason we deal with their genesis in detail here.

\section{Interpretation of the dome structures}

The dome structures have several characteristics in common with flame structures, but differ fundamentally from them because of their shape, particularly the length/width ratio. Flame structures form between adjacent descending lobes (load casts) at the contact between two successive layers that show a reversed density gradient (cf. Anketell et al. 1970; Allen 1982). The shape of such flames is controlled by the maturity of the load casts and by the lateral distance between them, but they tend to be more or less vertical and to have length/width ratios of the order of 10-100. Flame structures between seismically induced load structures, as described by, among others, Du et al. (2008), Owen et al. (2011) and Moretti and Ronchi (2011) show commonly much more distortion, depending on the complexity of the seismically induced load casts (which may become increasingly complex if successive seismic shocks affect them). Because of their irregular shapes, it is not well possible to attribute a specific length/width ratio to them, but this value does 
commonly not differ substantially from that of the first-mentioned type of flame structures.

The dome structures under study here have a much lower length/width ratio (order of $0.5-1)$, but they are also more regular than flame structures. In addition, the load structures in the sandy top part between the dome structures cannot have formed due to seismic activity because the layer in that case should show more - and particularly more laterally continuous - deformations. This implies that the dome structures must represent a process due to syn- or metadepositional conditions. The floating fragments consisting of the fine-grained sediment that now occur occasionally in the sandy part of the overlying turbidite must be ascribed to erosion of the parent layer of the fragments; this erosion is interpreted to have taken place under influence of the shearing caused by the downslope running turbidity current. The small kink folds show that the shear stress due to the movement of the turbidity current had a lateral component. Taking all these features into account, it must be deduced that rapid sedimentation of the overlying turbidite triggered the development of the dome structures.

The morphology of these dome structures results from the two main driving forces, viz. the gravitational instability due to a reverse density gradient (cf. Owen 1987, 1996, 2003; Owen et al. 2011; Rossetti 1999) and the lateral shear stress (cf. Mills 1983; Brenchley and Newall 1997; Dasgupta 1998; Moretti et al. 2001). During the rapid accumulation of ever more turbidites, the weight of the overburden caused, after passing a threshold value, partial liquefaction of the still unconsolidated sediments; these started to flow laterally (and partially upwards) together with the pore water, thus forming the dome structures without, however, to have sufficient power to break through the overlying layer. The laminae of the affected sediment 
313 thus became thicker in the domes, while thinning under the descending lobes of the

314 load structure.

315 The axial planes of some dome structures dip to the WNW and the micro-scale

316 kink folds indicate that the orientation of the shear stress was ESE-WNW; both

317 directions are consistent with the paleocurrent direction measured from the slump

318 folds and the sole marks. The shear stress that played such an important role in the

319 formation of the dome structures was probably induced by the drag of the turbidity

320 current, but it cannot be excluded entirely that the downslope component of the

321 gravitation of the overlying turbidite succession also played a role.

322

\section{Interpretation of the rip-up clasts}

324 Rip-up clasts are commonly considered to represent a seismically-induced autoclastic mudstone breccia (Wang 2013). Our field examples show clearly,

however, that the "clasts" are made up of fragments of the fine-grained sediment that became distorted when it became in immediate contact with the overlying sandstone turbidite. This must be deduced from the fact that the sandy base of the overlying turbidite was involved in a deformation process, whereas the fine-grained, laminated sediment does not show any obvious deformation. This suggest that the deformation occurred already during the deposition of the overlying turbidite. If the deformation were induced by a post-depositional process (such as a seismic shock), the finegrained top part of the overlying turbidite should also have been deformed, though not necessarily equally strongly. Moreover, the appearance of the fragments is not consistent with that of seismogenic autoclastic fragments which display brittle deformation and which fit harmoniously with each other (Anand and Jain 1987; 
al. 2011). Another argument against a seismogenic origin is that the strongly deformed fragments, which are distorted, stretched, folded and even overturned in a complicated way, are all attributable to the action of lateral shear stress, whereas these features cannot result from seismic shocks. A seismic trigger can consequently be ruled out; on the other hand, although the origin of rip-up clasts can have different origins, including diagenetically induced pressure (e.g. Henares et al. 2016), these types of structure have commonly been suggested to be induced by the passage of a strong flow such as a tsunami (Bondevik et al. 2003; Goff et al. 2004) or a turbidity current (Labaume et al. 1987), which also results in a sudden increase of the lithostatic pressure due to the rapid sedimentation of a turbidity current.

Deformations of the types described above develop when turbidity currents pass under a specific main driving force: lateral shear stress. Moreover, the rapidly thickened overburden resulted in the fluidization of the sandstone part of the underlying turbidite due to the increase of the pore pressure. The fluid/sediment mixture tried to escape upwards and penetrated the laminated fine-grained sediment. Possibly at the same time, the shear stress exerted by the passing turbidity current resulted in the complex deformation of the fragments. It can, however, not be entirely excluded that the shear stress resulting from the downslope component of the turbidites' weight contributed to the shear stress, particularly since some silty laminae in the fine-grained sediment became also liquefied.

\section{Discussion}

Numerous natural processes have the potential to trigger the development of SSDS in unconsolidated or semi-consolidated water-saturated sediments. The deformation mechanisms and driving forces can, however, in most cases be 
unraveled by analysis of the SSDS (cf. Suter et al. 2011). The interpretation of the most likely trigger mechanism, in contrast, is commonly much more difficult to define, particularly since different triggers can induce SSDS with similar morphologies, whereas it is known already for a long time that one single trigger can result in SSDS with strongly different morphologies (Kuenen 1958; Butrym et al. 1964; Dzulynski and Walton 1965). This makes it difficult to recognize triggers for complex SSDS such as those that characterize, for instance, seismites. It is therefore understandable that contrasting approaches have been proposed to distinguish seismic triggers (criteriabased approach) from non-seismic triggers (trigger-based approach) (Pope et al. 1997; Jones and Omoto 2000; Moretti 2000; Moretti and Sabato 2007; Spalluto et al. 2007; Owen et al. 2011), and even such approaches have to deal with numerous pitfalls (Moretti and Van Loon 2014).

Few criteria have, unfortunately, been developed thus far to identify non-seismic triggers. Moretti and Sabato (2007) suggested to identify them by analyzing each possible trigger using all available information to accept or discard a specific trigger. This approach is, however, not only comprehensive, but it is difficult - if not impossible - to consider all potential triggers for each individual SSDS. Owen et al. (2011) therefore suggested a three-stage approach, combining assessment of (1) the sedimentary facies, (2) likely triggers and (3) available criteria. We follow this approach here.

(1) With respect to the facies assessment, it is clear that the SSDS under study developed in turbidite successions which were deposited in an outer-fan/basin-plain environment. All SSDS are situated at the boundaries between the fine-grained top parts of a sandstone turbidite and the sandstone part of an overlying turbidite. It is remarkable that the fine-grained top part of the latter (the overlying turbidite) is 
undeformed, which proves that the deformation must have occurred syndepositionally (i.e. during deposition of the overlying turbidite) or (much less likely) metadepositionally, i.e., before deposition of the overlying turbidite. This close relationship suggests that the trigger is associated with the depositional process so that triggers that are not associated with depositional processes (such as seismic shocks, bioturbation and impacts) can be excluded.

(2) With respect to the trigger assessment, it is important, because we proved above that the trigger was most probably syndepositional and thus should be considered as inherent to the depositional environment, that numerous triggers (particularly rapid sedimentation, storm waves, breaking waves, flow impact, a tsunami, tidal shearing and groundwater movement) need be assessed. According to the water depth in this sedimentary environment, most triggers, such as storm waves, breaking waves, tsunamis and tidal shear can fortunately be discarded. In addition, the deformational structures are not similar with those induced by flow-induced shear or groundwater movement. Therefore, rapid sedimentation remains as the most likely trigger.

(3) With respect to the criteria assessment, some probable criteria have already been proposed to characterize SSDS in turbidite successions that are related to rapid sedimentation. These criteria are based on the characteristics of the SSDS and their sedimentary context, and they include the following situations: (1) the turbidite overlying the level with the SSDS shows no obvious liquefaction-induced feature in its sandstone part; (2) the fine-grained part of the overlying turbidite is still undeformed; (3) the preferred orientation of some structures may have been caused by shear stress, and they are consistent with the paleocurrent direction. 


\section{Conclusions}

414 Dome structures and rip-up clasts occur in Early Cretaceous turbidite successions 415 exposed in the Dengta and Qiancengya sections on Lingshan Island, eastern China.

416 The turbidites with these SSDS tend to consist of thin-bedded sandstones that

417 alternate with finely laminated fine-grained sediments. The sediments accumulated in 418 an outer-fan/basin-plain setting characterized by low-energy conditions. The dome 419 structures and rip-up clasts result from liquefaction/fluidization induced by the rapidly 420 increasing weight of the overburden caused by the high sedimentation rate of 421 successive turbidites, which is a common feature in such types of succession.

422 The dome structures have a genesis (Fig. 7) that is in several respects comparable 423 to that of flame structures: overloading induced by the sudden deposition of a sandy 424 turbidite caused the finely laminated fine-grained, water-saturated sediment to be 425 pushed aside between sagging sand lobes of the freshly deposited layer; this was 426 facilitated because the fine-grained sediment became partially liquefied, enabling them to flow sidewards and somewhat upwards into the direction of least pressure (= upwards). The energy of the moving sediment/water mixture was, in contrast to the situation where a zone of weakness allows such a mixture to open a pathway through 430 the overlying layer, relatively small, so that the overlying sediment could not (or only as a very small scale) be penetrated, so that only a dome-shaped accumulation was formed with laminae that thicken towards the axial part. The shear stress exerted by the turbidity current caused a preferred orientation (NW) of some axial planes of the dome structures, consistent with the overall paleocurrent direction.

435 The rip-up clasts of the finely laminated, fine-grained sediments developed due to 436 the fluidization of the sandstone part of the underlying turbidite caused by the sudden 437 overloading due to the rapidly deposited overlying sandstone turbidite (Fig. 8). The 
438 excess water rushed out, to rupture the fine-grained sediment. The shear stress

439 exerted by the passing turbidity current complicated the deformation process,

440 resulting in stretched, distorted and folded clasts.

441

442 Acknowledgements

443 This work was supported by grants from the National Science Foundation of China 444 (41322013) and the Department of Science \& Technology of Shandong Province 445 (2017CXGC1608). Zhao Liang thanks team mate Dr. Andong Wang for his 446 preliminary and basic work in the study area and for his advice. He also thanks 447 Tengfei Zhou, Wendong Liang and Huiwen Yue for their assistance in the field work. 448 
449

450

451

452

453

454

455

456

457

458

459

460

461

462

463

464

465

466

467

468

469

470

471

472

473

\section{References}

Allen, J.R.L. 1977. The possible mechanics of convolute lamination in graded sand beds. Journal of the Geological Society, 134: 19-31. doi:10.1144/gsjgs.134.1.0019.

Allen, J.R.L., 1982. Sedimentary Structures, Their Character and Physical Basis, Vol. 2. Developments in Sedimentology (Elsevier, Amsterdam), 30B: 663 pp.

Allen, J.R.L., and Banks, N.L. 1972. An interpretation and analysis of recumbentfolded deformed crossbedding. Sedimentology, 19: 257-83. doi:10.1111/j.13653091.1972.tb00024.x.

Anketell, J.M., Cegla, J., and Dzulynski, S., 1970. On the deformational structures in systems with reversed density gradients. Rocznik Polskiego Towarzystwa Geologicznego, 40: 3-30.

Anand, A., and Jain, A.K. 1987. Earthquakes and deformational structures (seismites) in Holocene sediments from the Himalayan-Andaman Arc, India. Tectonophysics, 133: 105-120. doi:10.1016/0040-1951(87)90284-8.

Berra, F., and Felletti, F. 2011. Syndepositional tectonics recorded by soft-sediment deformation and liquefaction structures (continental Lower Permian sediments, Southern Alps, Northern Italy): stratigraphic significance. Sedimentary Geology, 235: 249-263.doi:10.1016/j.sedgeo. 2010.08.006.

Bondevik, S., Mangerud, J., Dawson, S., Dawson, A., and Lohne, $\varnothing .1984$. Recordbreaking height for 8000-year-old tsunami in the North Atlantic. Eos, 84: 289-293. doi:10.1029/2003EO310001.

Brenchley, P.J., and Newall, G. 1977. The significance of contorted bedding in upper Ordovician sediments of the Oslo region, Norway. Journal of Sedimentary Research, 47: 819-833. 
474 Butrym, J., Cegla, J., Dzulynski, S., and Nakonieczny, S., 1964. New interpretation of $475 \quad$ periglacial structures. Folia Quaternaria, 17: 1-34.

476 Dasgupta, P. 1998. Recumbent flame structures in the Lower Gondwana rocks of the 477 Jharia Basin, India - a plausible origin. Sedimentary Geology, 119: 253-261. doi:10.1016/S0037-0738(98)00058-X.

Du, Y. 2011. Discussion about studies of earthquake event deposit in China. Journal

Feng, Z.,Bao, Z.,Zheng, X., and Wang, Y., 2016. Researches of soft-sediment deformation structures and seismites in China - A brief review. Journal of Palaeogeography, 5: 311-317. doi:10.1016/j.jop.2016.06.001.

Field, M.E., Gardner, V., Jennings, A.E., and Edwards, B.D. 1982. Earthquake induced sediment failures on a $0.25^{\circ}$ slope, Klamath River delta, California. Geology, 10: 542-546. doi:10.1130/0091-7613(1982)10<542:ESFOAS>2.0.CO;2.

Goff, J., McFadgen, B.G., and Chagué-Goff, C. 2004. Sedimentary differences between the 2002 Easter storm and the 15th-century Okoropunga tsunami, 

southeastern North Island, New Zealand. Marine Geology, 204: 235-250. doi.org/10.1016/S0025-3227(03)00352-9.

Guiraud, M., and Plaziat, J.C. 1993. Seismites in the fluviatile Bima sandstones: Identification of paleoseisms and discussion of their magnitudes in a Cretaceous synsedimentary strike-slip basin (Upper Benue, Nigeria). Tectonophysics, 225: 493-522. doi:10.1016/0040-1951(93)90312-8.

He, B., Qiao, X., Zhang, Y., Tian, H., Cai, Z., Chen, S., and Zhang, Y., 2015. Softsediment deformation structures in the Cretaceous Zhucheng Depression, Shandong Province, East China; their character, deformation timing and tectonic implications. Journal of Asian Earth Sciences, 110: 101-122. doi:10.1016/j.jseaes.2014.12.005.

Henares, S., Arribas, J., Cultrone, G., and Viseras, C. 2016. Muddy and dolomitic ripup clasts in Triassic fluvial sandstones: Origin and impact on potential reservoir properties (Argana Basin, Morocco). Sedimentary Geology, 339: 218-233. doi:10.1016/j.sedgeo.2016.03.020.

Hilbert-Wolf, H.L., Simpson, E.L., Simpson, W.S., Tindall, S.E., and Wizevich, M.C., 2009. Insights into syndepositional fault movement in a foreland basin; trends in seismites of Upper Cretaceous Wahweap Formation, Kaiparowits Basin, Utah, USA. Basin Research, 21: 856-871. doi:10.1111/j.1365-2117.2009.00398.x.

Jones, A.P., and Omoto, K. 2000. Towards establishing criteria for identifying trigger mechanisms for soft-sediment deformation: a case study of Late Pleistocene lacustrine sands and clays, Onikobe and Nakayamadaira Basins, northeastern Japan. Sedimentology, 47: 1211-1226. doi:10.1046/j.1365-3091.2000.00355.x. Kuenen, Ph.H., 1958. Experiments in geology. Transactions, Geological Society Glasgow, 23: 1-28. doi:10.1144/transglas.23.centenary.1. 
523 Labaume, P., Mutti, E., and Seguret, M. 1987. Megaturbidites: A depositional model

524 from the Eocene of the SW-Pyrenean Foreland basin, Spain. Geo-Marine Letters, 525 7: 91-101. doi:10.1007/BF02237988.

Li, S., Liu, X., Suo, Y., Liu, L., Qian, C., Liu, X., Zhang, G., and Zhao, G. 2009. Triassic folding and thrusting in the Eastern Block of the North China Craton and

Lowe, D.R. 1975. Water escape structures in coarse-grained sediments. the Dabie-Sulu orogeny and its geodynamics. Acta Petrologica Sinica, 25: 20312049. (in Chinese with English abstract).

Sedimentology, 22: 157-204. doi:10.1111/j.1365-3091.1975.tb00290.x.

Lu, H., Wang, J., and Zhang, H. 2011. Discovery of the late Mesozoic slump beds in Lingshan Island, Shandong, and a pilot research on the regional tectonics. Acta Geologica Sinica, 85: 938-946. (in Chinese with English abstract).

Lu, H., Zhang, H., Wang, J., Dong, X., and Zhang, X., 2012. A giant olistolith discovered in the late Mesozoic turbidites in Lingshan Island, Jiaonan, Shandong. Geological Review, 58: 80-81(in Chinese).

Luan, G., Li, A., Wang, J., Li, G., and Xie, R. 2010. The geological origin division of the main sea island in Qingdao area and environment analysis. Periodical of Ocean University of China, 40: 111-116. (in Chinese with English abstract).

Mills, P.C. 1983. Genesis and diagnostic value of soft-sediment deformation structures-a review. Sedimentary Geology, 35: 83-104. doi:10.1016/00370738(83)90046-5.

Moretti, M. 2000. Soft-sediment deformation structures interpreted as seismites in middle-late Pleistocene aeolian deposits (Apulian foreland, southern Italy). Sedimentary Geology, 135: 167-179. doi:10.1016/S0037-0738(00)00070-1. 
547 Moretti, M., and Van Loon, A.J. 2014. Restrictions to the application of 'diagnostic'

$548 \quad$ criteria for recognizing ancient seismites. Journal of Palaeogeography, 3: 162-

549 173. doi:10.3724/SP.J.1261.2014.00050.

550 Moretti, M., and Ronchi, A. 2011. Liquefaction features interpreted as seismites in the

551 Pleistocene fluvio-lacustrine deposits of the Neuquén Basin (northern Patagonia).

552 Sedimentary Geology, 235: 200-209. doi:10.1016/j.sedgeo.2010.09.014.

553 Moretti, M., and Sabato, L. 2007. Recognition of trigger mechanisms for soft-

554 sediment deformation in the Pleistocene lacustrine deposits of the

555 Sant'Arcangelo Basin (southern Italy): seismic shock vs. overloading.

556 Sedimentary Geology, 196: 31-45. doi:10.1016/j.sedgeo.2006.05.012.

557 Moretti, M., Soria, J.M., Alfaro, P., and Walsh, N. 2001. Asymmetrical soft-sediment

558 deformation structures triggered by rapid sedimentation in turbiditic deposits

559 (Late Miocene, Guadix Basin, southern Spain). Facies, 44: 283-294.

560 doi:10.1007/BF02668179.

561 Mutti, E., and Ricci Lucchi, F. 1978. Turbidites of the northern Apennines.

562 Introduction to facies analysis. International Geology Review, 20: 125-166.

563 doi:10.1080/00206817809471524.

564 Obermeier, S.F., 1996. Use of liquefaction-induced features for paleoseismic analysis

$565-$ An overview of how seismic liquefaction features can be distinguished from

566 other features and how their regional distribution and properties of source

567 sediment can be used to infer the location and strength of Holocene paleo-

568 earthquakes. Engineering Geology, 44: 1-76. doi:10.1016/S0013-

$569 \quad$ 7952(96)00040-3.

570 Oliveira, C.M.M., Hodgson, D.M., and Flint, S.S., 2011. Distribution of soft-sediment

571 deformation structures in clinoform successions of the Permian Ecca Group, 
Karoo Basin, South Africa. Sedimentary Geology, 235: 314.330. doi:10.1016/j.sedgeo.2010.09.011.

Owen, G. 1987. Deformation processes in unconsolidated sands. In Deformation of Sediments and Sedimentary Rocks. Edited by M.E. Jones, and R.M.F. Preston. Geological Society, London, Special Publication, 29, pp. 11-24.

Owen, G. 1996. Experimental soft-sediment deformation structures formed by the liquefaction of unconsolidated sands and some ancient examples. Sedimentology, 43: 279-293. doi:10.1046/j.1365-3091.1996.d01-5.x.

Owen, G. 2003. Load structures: gravity-driven sediment mobilization in the shallow subsurface. In Subsurface Sediment Mobilization. Edited by P. Van Rensbergen, R.R. Hillis, A.J. Maltman, and C.K. Morley. Geological Society, London, Special Publication, 216, pp. 21-34.

Owen, G., and Moretti, M., 2011. Identifying triggers for liquefaction-induced softsediment deformation in sands. Sedimentary Geology, 235: 141-147. doi:10.1016/j.sedgeo.2010.10.003.

Owen, G., Moretti, M., and Alfaro, P. 2011. Recognising triggers for soft-sediment deformation: Current understanding and future directions. Sedimentary Geology, 235: 133-140. doi:10.1016/j.sedgeo.2010.12.010.

Plaziat, J.C., Purser, B.H., and Philobbos, E.R. 1990. Seismic deformation structures (seismites) in the syn-rift sediments of the NW Red Sea (Egypt). Bulletin de la Société Géologique de France, 6: 419-434. doi:10.2113/gssgfbull.VI.3.419.

Pope, M.C., Read, J.F., Bambach, R., and Hofmann, H.J. 1997. Late Middle to Late Ordovician seismites of Kentucky, southwest Ohio and Virginia: Sedimentary recorders of earthquakes in the Appalachian Basin. Geological Society of 
America Bulletin, 109: 489-503. doi:10.1130/00167606(1997)109<0489:LMTLOS>2.3.CO;2.

Qiao, X., and Li, H. 2009. Effect of earthquake and ancient-earthquake on sediments. Journal of Palaeogeography, 11: 593-610. (in Chinese with English abstract).

Rossetti, D.F. 1999. Soft-sediment deformation structures in late Albian to Cenomanian deposits, São Luís Basin, northern Brazil: Evidence for palaeoseismicity. Sedimentology, 46, 1065-1081. doi:10.1046/j.13653091.1999.00265.x.

Rossetti, D.F., Bezerra, F.H.R., Góes, A.M., and Neves, B.B.B. 2011. Sediment deformation in Miocene and post-Miocene strata, northeastern Brazil: Evidence for paleoseismicity in a passive margin. Sedimentary Geology, 235: 172-187. doi:10.1016/j.sedgeo.2010.02.005.

Sanders, J.E. 1956. Oriented phenomena produced by sedimentation from turbidity currents and in subaqueous slope deposits. Journal of Paleontology, 30: 997997. doi:10.1306/74D7051F-2B21-11D7-8648000102C1865D.

SBGMR (Shandong Bureau of Geology and Mineral Resources), 1991. Shandong Regional Geological Annals. Geological Publishing House, Beijing, 639 pp. (in Chinese).

Shao, Z., Zhong, J., Li, Y., Mao, C., Liu, S., Ni, L., Tian, Y., Cui, X., Liu, Y., Wang, X., Li, W., and Lin, G. 2014.Characteristics and sedimentary processes of laminacontrolled sand-particle imbricate structure in deposits of Lingshan Island, Qingdao, China. Science China: Earth Sciences, 57: 1061-1076. doi:10.1007/s11430-014-4848-x. 
619 Sims, J.D., 1975. Determining earthquake recurrence intervals from deformational 620 structures in young lacustrine sediments. Tectonophysics, 29: 141-152.

621

622

623

624

625

Suter, F., Martínez, J.I., and Vélez, M.I. 2011. Holocene soft-sediment deformation of

Stromberg, S.G., and Bluck, B. 1998. Turbidite facies, fluid-escape structures and mechanisms of emplacement of the Oligo-Miocene Aljibe Flysch, Gibraltar Arc, Betics, southern Spain. Sedimentary Geology, 115: 267-288. doi:10.1016/S0037-0738(97)00096-1. the Santa Fe-Sopetrán Basin, northern Colombian Andes: Evidence for prehispanic seismic activity? Sedimentary Geology, 235: 188-199. doi:10.1016/j.sedgeo.2010.09.018.

Tinterri, R., Magalhaes, P.M., Tagliaferri, A., and Cunha, R.S. 2016. Convolute laminations and load structures in turbidites as indicators of flow reflections and decelerations against bounding slopes. Examples from the Marnoso-arenacea Formation (northern Italy) and Annot Sandstones (south eastern France). Sedimentary Geology, 344: 382-407. doi:10.1016/j.sedgeo.2016.01.023.

Van Loon, A.J., 2009. Soft-sediment deformation structures in siliciclastic sediments: an overview. Geologos, 15: 3-55.

Wang, A. 2013. Research on the Soft-sediment Deformation Structures in the Early Cretaceous Strata at Lingshan Island, Shandong. China University of Petroleum (East China), Qingdao. (in Chinese with English abstract). 
644 Wang, J., Chang, S., Lu, H., and Zhang, H., 2014. Detrital zircon U-Pb age

645 constraints on Cretaceous sedimentary rocks of Lingshan Island and

646 implications for tectonic evolution of eastern Shandong, north China. Journal of

647 Asian Earth Sciences, 96: 27-45. doi:10.1016/j.jseaes.2014.09.002.

648 Wheeler, R.L., 2002. Distinguishing seismic from nonseismic soft-sediment structures:

649 Criteria from seismic-hazard analysis. In Ancient Seismites. Edited by F.R.

650 Ettensohn, N. Rast, and C.E. Brett. The Geological Society of America Special

651 Paper, 359: 1-11. doi:10.1130/0-8137-2359-0.1.

652 Wu, F., Lin, J., Wilde, S.A., Zhang, X., and Yang, J. 2005. Nature and significance of

653 the Early Cretaceous giant igneous event in eastern China. Earth and Planetary

654 Science Letters, 233:103-119. doi:10.1016/j.epsl.2005.02.019.

655 Yang R., Fan A., Han Z., and Van Loon, A.J. 2016. An upward shallowing succession

656 of gravity flow deposits in the Early Cretaceous Lingshandao Formation, western

657 Yellow Sea. Acta Geologica Sinica (English Edition), 90: 1553-1554.

658 doi:10.1111/1755-6724.12793.

659 Yang, R., Fan, A., Han, Z., and Van Loon, A.J., 2017. A marine or continental nature

660 of the deltas in the Early Cretaceous Lingshandao Formation - Evidences from

661 trace elements. Acta Geologica Sinica (English Edition), 91: 367-368.

662 Yang, R., and Van Loon, A.J. 2016. Early Cretaceous slumps and turbidites with

663 peculiar soft-sediment deformation structures on Lingshan Island (Qingdao,

664 China) indicating a tensional tectonic regime. Journal of Asian Earth Sciences,

665 129: 206-219. doi:10.1016/j.jseaes.2016.08.014.

666 Zhang, H., Lu H., Li, J., Wang, J., Zhang, S., Dong, X., Zhang, X., Huang, Z., Shu, Y.,

667 and Ren, X. 2013. The Lingshandao Formation: a new lithostratigraphic unit of 
668 the Early Cretaceous in Qingdao, Shandong, China. Journal of Stratigraphy, 37:

669 216-222. (in Chinese with English abstract).

670 Zhong, J., 2012. The Mesozoic sedimentary rocks on Lingshan Island: are they

671 deepwater far-sourced turbidites or intra-continental deltaic sediments? - A

672 discussion with Prof. Lu Hongbo. Geological Review, 58: 1180-1182 (in Chinese).

673 Zhou, Y., Zhang, Z., Liang, W., Li, S., and Yue, H. 2015. Late Mesozoic tectono-

674 magmatic activities and prototype basin restoration in eastern Shandong

675 Province, China. Earth Science Frontiers, 22: 137-156. (in Chinese with English

$676 \quad$ abstract). doi:10.13745/j.esf.2015.01.012.

677 


\section{8 [Figure captions]}

679

680

681

682

683

684

685

686

687

688

689

690

691

692

693

694

695

696

697

698

699

700

701

702

Fig. 1. Geographical and geological setting. (a) Location of the study area, with the Sulu Orogenic Belt between the North China Plate and the Yangtze Plate. (b)

Geological setting of the Shandong region, with Lingshan Island (indicated in red)

being situated in the Lingshandao Depression. (c) Geological map of Lingshan Island, with locations of the two sections under study. (d) Stratigraphic framework and sedimentological setting of Lingshan Island.

Fig. 2. Paleocurrent data. (a) Stereonet plots of fold axes (open squares) and axialplane poles (crosses) of the folds in slumps $(n=20)$. (b) Rose diagram of paleocurrent directions measured from flute casts. (c) Rose diagram of paleocurrent directions measured from groove casts.

Fig. 3. The Dengta section. The succession (a) consist mainly of turbidites (b) that each consist of a graded lower sandstone part and a finely laminated fine-grained upper part. Some slumps are also present, ranging from meters thick (b) to some decimeters thick (c). (diameter of the lens cap is $6 \mathrm{~cm}$ ).

Fig. 4. The Qiancengya section. the succession (a) consists mainly of thin-bedded sandstones alternating with fine-grained layers (b). (c) detail of the succession (diameter of the tape holder is $20 \mathrm{~cm}$ ).

Fig. 5. Dome structures in the Dengta section. (a) Setting of a well-developed specimen between a fine-grained unit and the sandy basal part of an overlying 
703

704

705

706

707

708

709

710

711

712

713

714

715

716

717

718

719

720

721

722

723

724

turbidite. (b) Detail of the structure in Fig. 5a. (c) Undulating laminae (dashed lines)

toward the axial plane of a dome structure. Pen $(1 \mathrm{~cm}$ in diameter) for scale.

Fig. 6. Rip-up clasts at the base of the Qiancengya section. (a) Partly undeformed fragment (left) and disrupted fragments of broken-up lamination (right) in a finegrained layer. (b) Deformed (distorted, stretched, folded) fragments of the same layer, also showing layer thickening and thinning. (c) Folded laminae inside the fine-grained laminated bed (the axial plane dips to the NNW). (d) Large folded fragment of the laminated sediment. Pen $(1 \mathrm{~cm}$ in diameter $)$ for scale.

Fig. 7. Schematic model showing the genesis of the dome structures. (a): deposition of a turbidite on a turbidite substratum. (b) a sand-rich turbidity current flows over the older turbidite. (c) dome structures form in the liquefied sediment due to overloading and lateral shear caused by deposition of the sand-rich lower part of the turbidite. (d) deposition of the fine-grained upper part of the turbidite, preserving the dome structure.

Fig. 8. Schematic model showing the genesis of the rip-up clasts. (a) deposition of a turbidite on a turbidite substratum. (b) escape of water/sediment mixtures; (c) rip-up clasts form in the liquefied sediment due to the erosional power and lateral shear exerted by the sand-rich lower part of the turbidity current. (d) deposition of the finegrained upper part of the turbidite, preserving the rip-up clasts. 

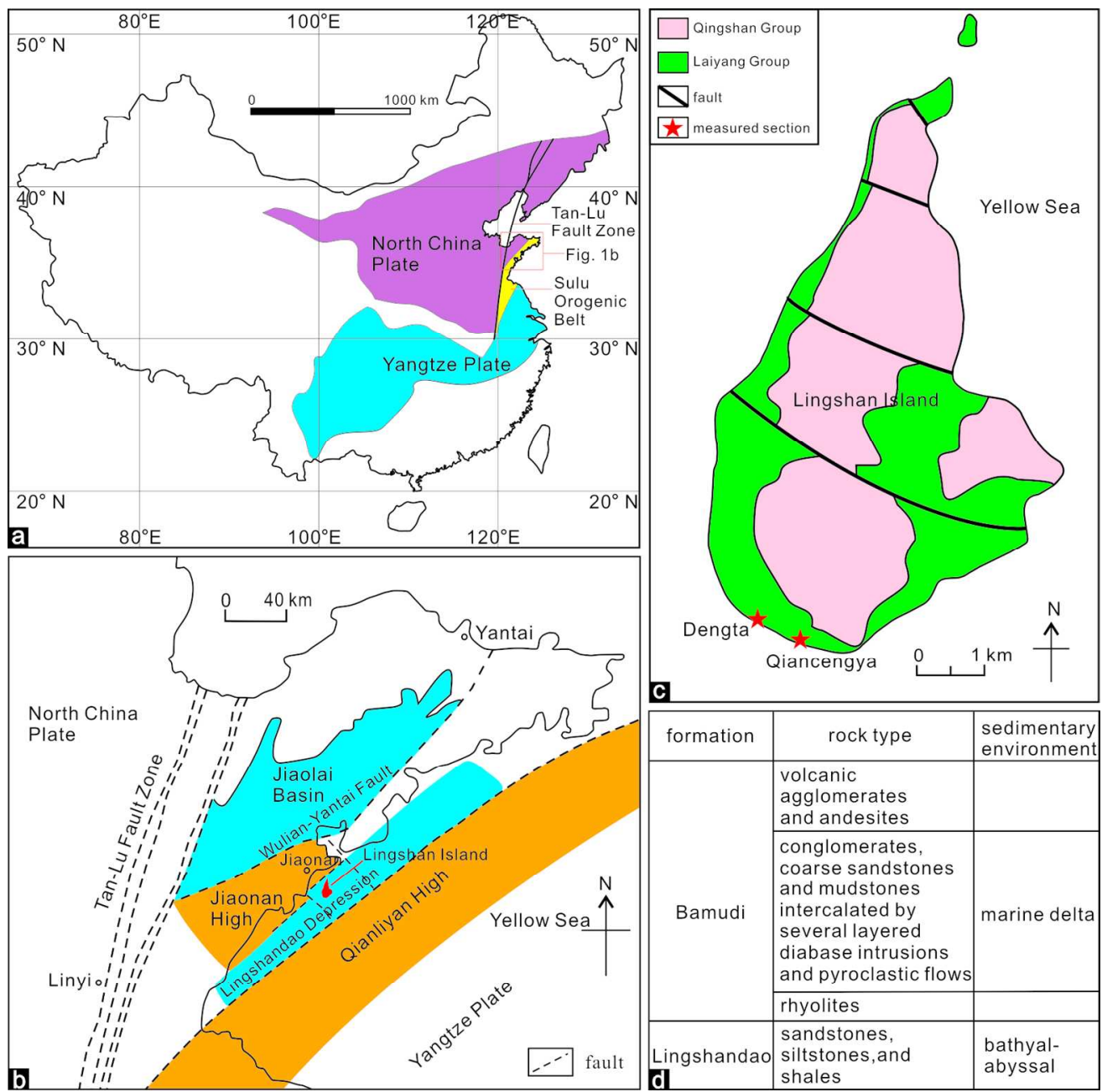

Fig .1. Geographical and geological setting. (a) Location of the study area, with the Sulu Orogenic Belt between the North China Plate and the Yangtze Plate. (b) Geological setting of the Shandong region, with Lingshan Island (indicated in red) being situated in the Lingshandao Depression. (c) Geological map of Lingshan Island, with locations of the two sections under study. (d) Stratigraphic framework and sedimentological setting of Lingshan Island.

$141 \times 140 \mathrm{~mm}(300 \times 300$ DPI $)$ 


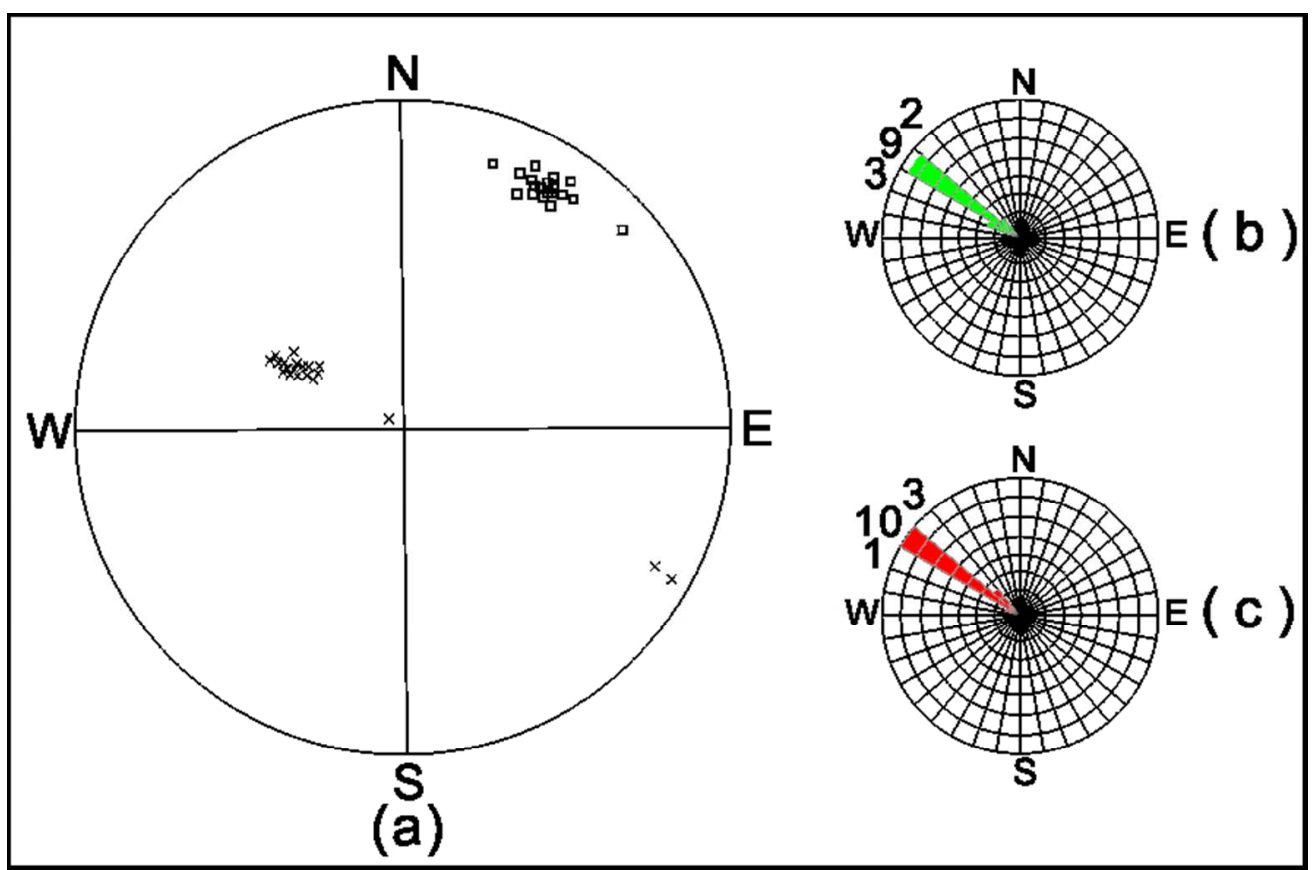

Fig. 2. Palaeocurrent data. (a) Stereonet plots of fold axes (open squares) and axial-plane poles (crosses) of the folds in slumps $(n=20)$. (b) Rose diagram of palaeocurrent directions measured from flute casts. (c) Rose diagram of palaeocurrent directions measured from groove casts.!! +

$$
75 \times 49 \mathrm{~mm}(300 \times 300 \mathrm{DPI})
$$




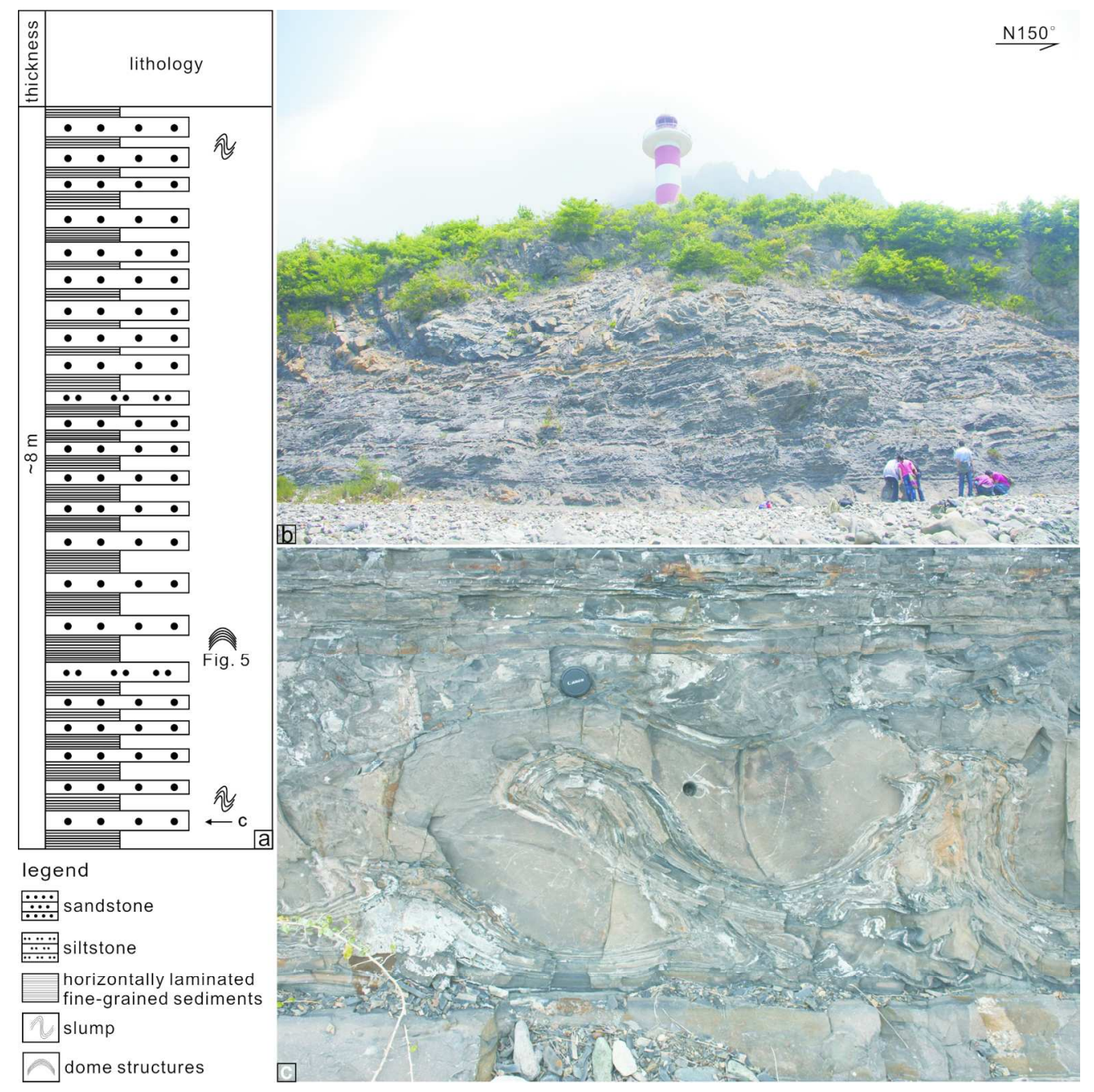

Fig. 3. The Dengta section. The succession (a) consist mainly of turbidites (b) that each consist of a graded lower sandstone part and a finely laminated fine-grained upper part. Some slumps are also present, ranging from meters thick (b) to some decimeters thick (c). (diameter of the lens cap is $6 \mathrm{~cm}$ ).

$146 \times 148 \mathrm{~mm}(300 \times 300 \mathrm{DPI})$ 


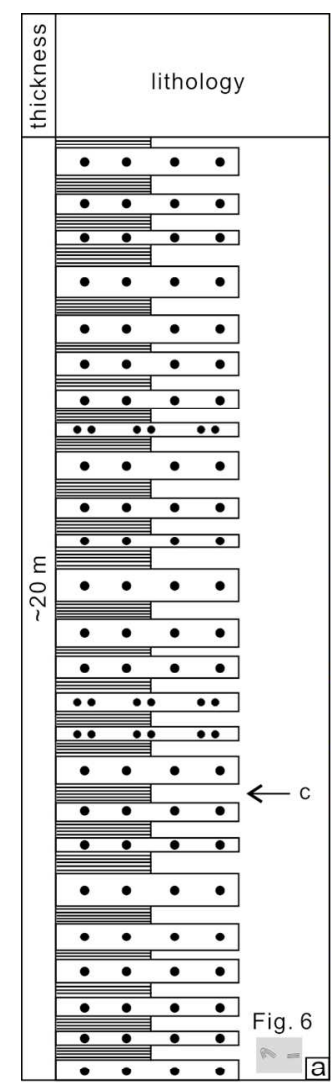

legend

$\because \cdots$ sandstone

…:... siltstone

horizontally laminated
fine-grained sediments

$\Rightarrow$ rip-up clasts

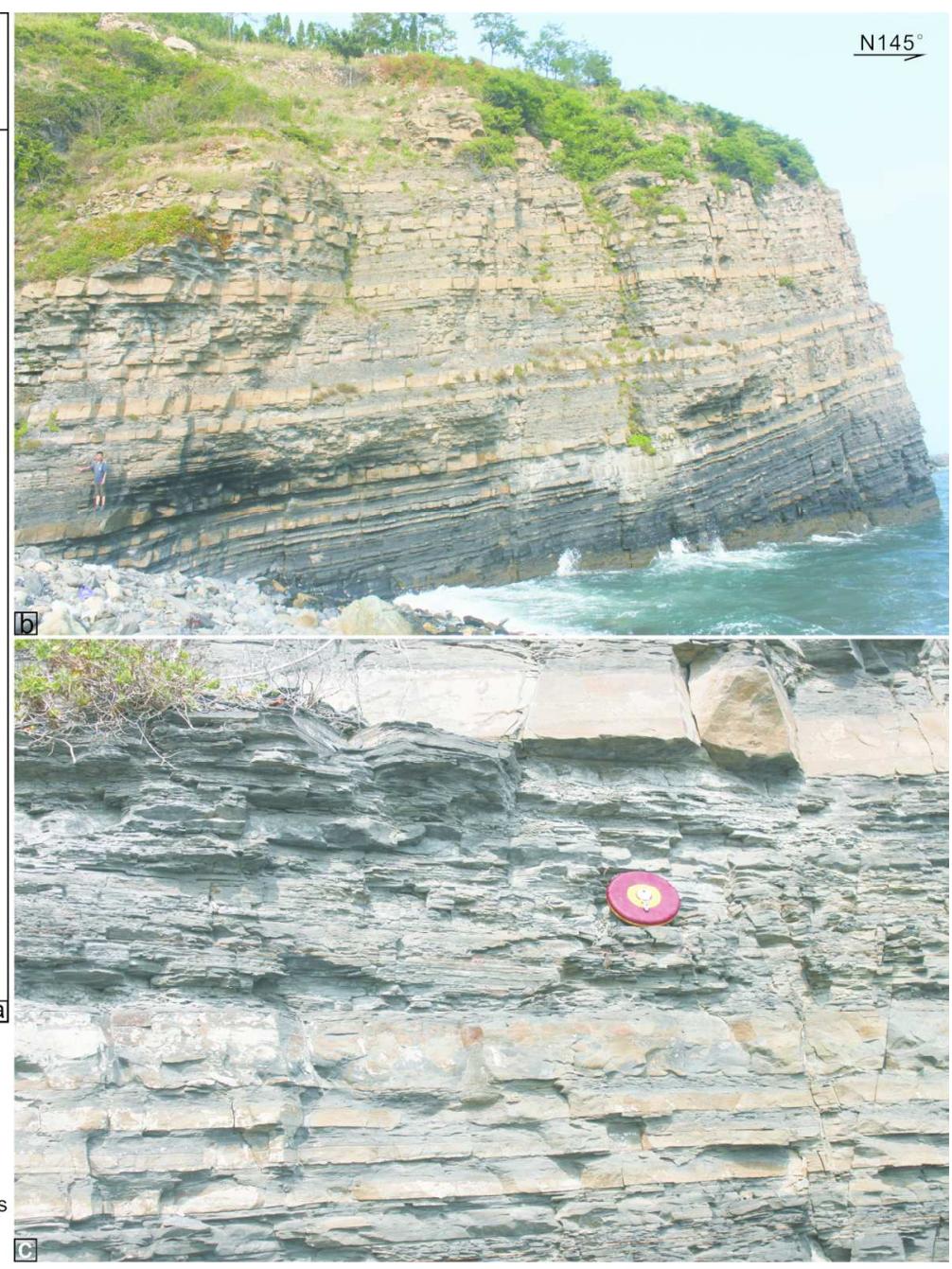

Fig. 4. The Qiancengya section. the succession (a) consists mainly of thin-bedded sandstones alternating with fine-grained layers (b). (c) detail of the succession (diameter of the tape holder is $20 \mathrm{~cm}$ ).

$141 \times 143 \mathrm{~mm}(300 \times 300 \mathrm{DPI})$ 

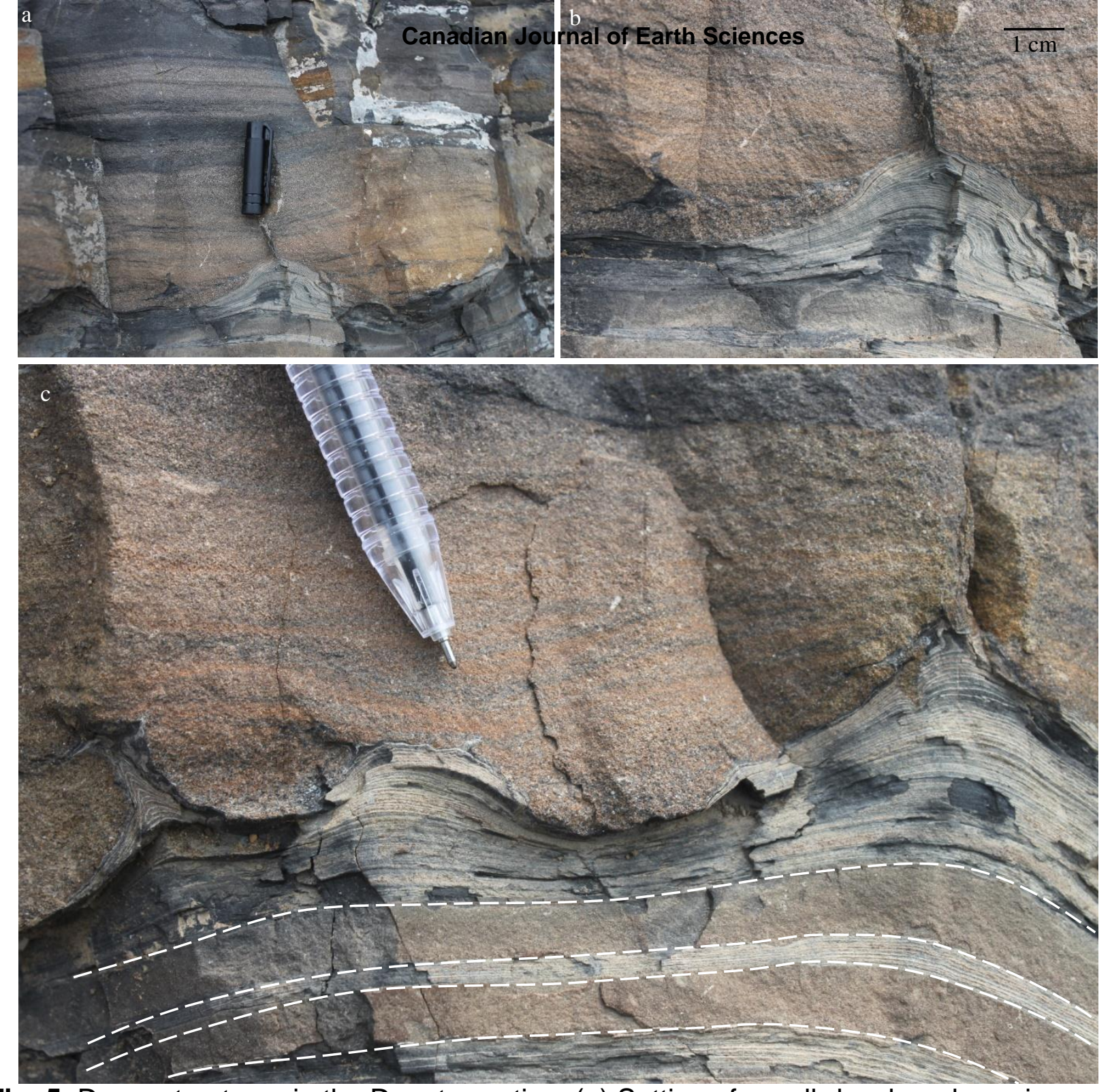

Fig. 5. Dome structures in the Dengta section. (a) Setting of a well-developed specimen between a fine-grained unit and the sandy basal part of an overlying turbidite. (b) Detail of the structure in Fig. 5a. (c) Undulating laminae (dashed lines) toward the axial plane of a

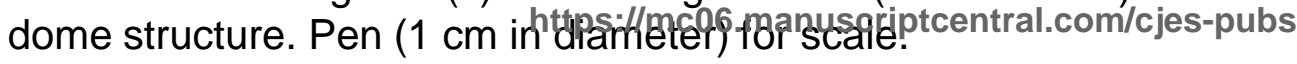

$161 \times 162 \mathrm{~mm}(96 \times 96 \mathrm{DPI})$ 


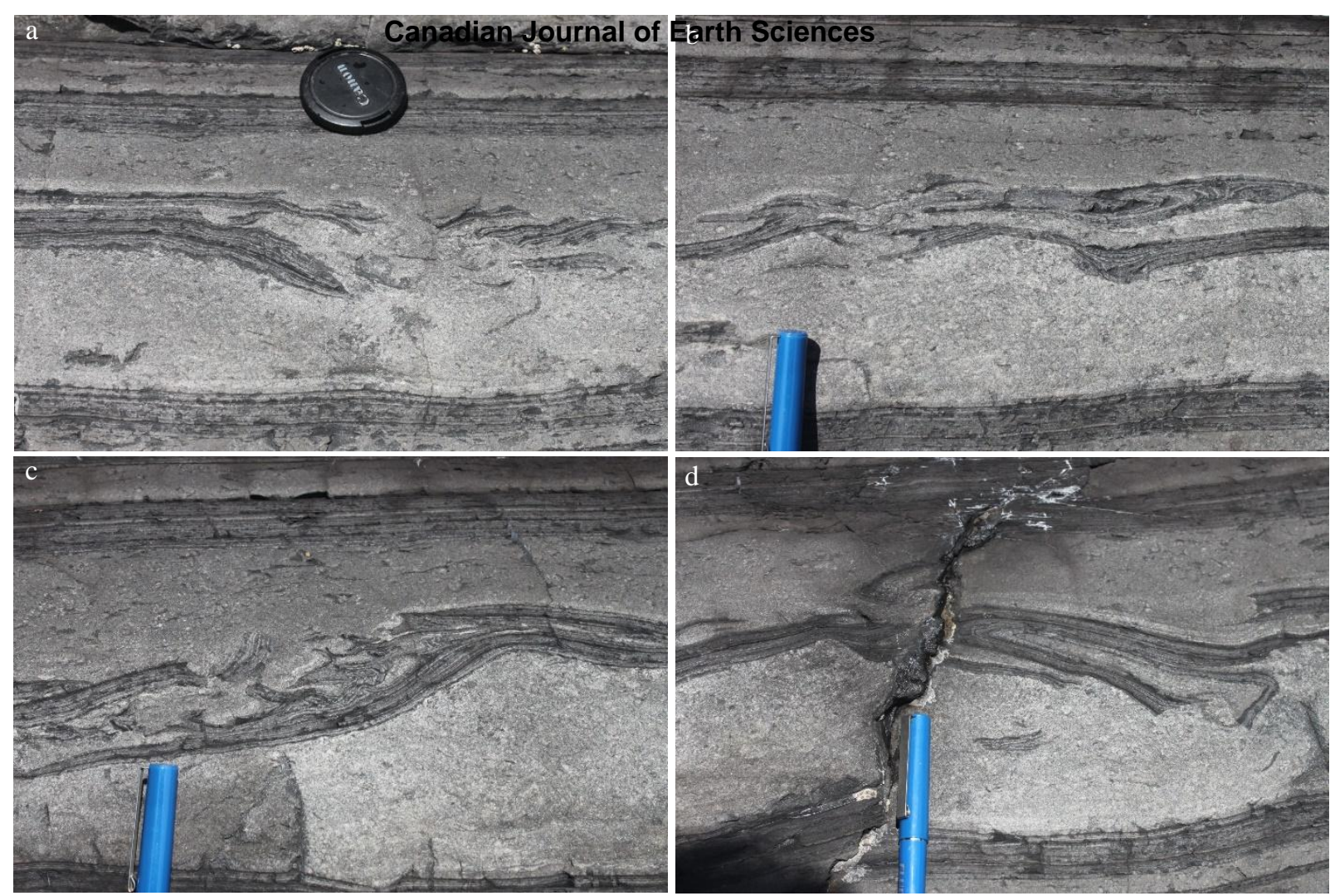

Fig. 6. Rip-up clasts from the base of the Qiancengya section. (a) Partly undeformed fragment (left) and disrupted fragments of broken-up lamination (right) in a fine-grained layer. (b) Deformed (distorted, stretched, folded) fragments of the same layer, also showing layer thickening and thinning. (c) Folded laminae inside the fine-grained laminated bed (the axial plane dips to the NNW). (d) Large folded fragment of the laminated sediment. Pen (1 $\mathrm{cm}$ in diameter) for scale.

$161 \times 108 \mathrm{~mm}(96 \times 96 \mathrm{DPI})$ 

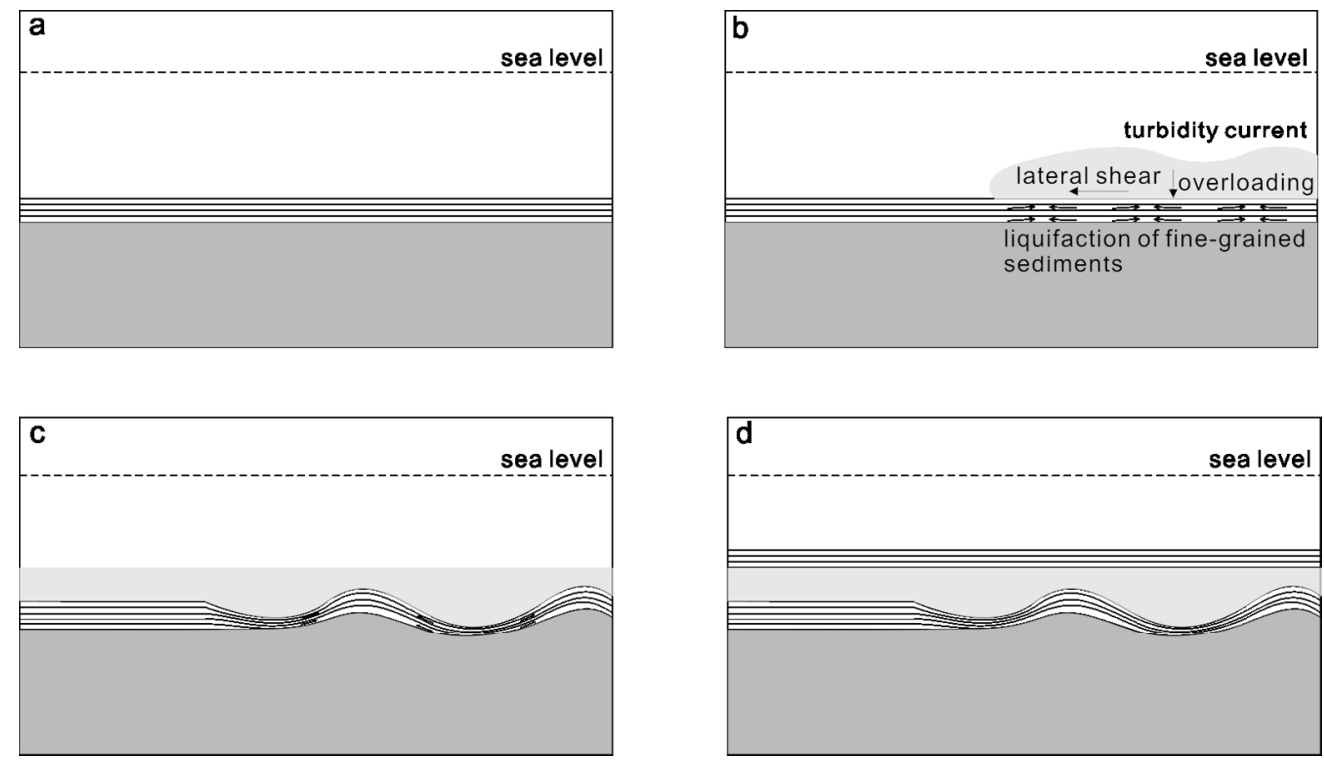

Fig. 7. Schematic model showing the genesis of the dome structures. (a): deposition of a turbidite on a turbidite substratum. (b) a sand-rich turbidity current flows over the older turbidite. (c) dome structures form in the liquefied sediment due to overloading and lateral shear caused by deposition of the sand-rich lower part of the turbidite. (d) deposition of the fine-grained upper part of the turbidite, preserving the dome structure.!! +

$134 \times 77 \mathrm{~mm}(300 \times 300 \mathrm{DPI})$ 

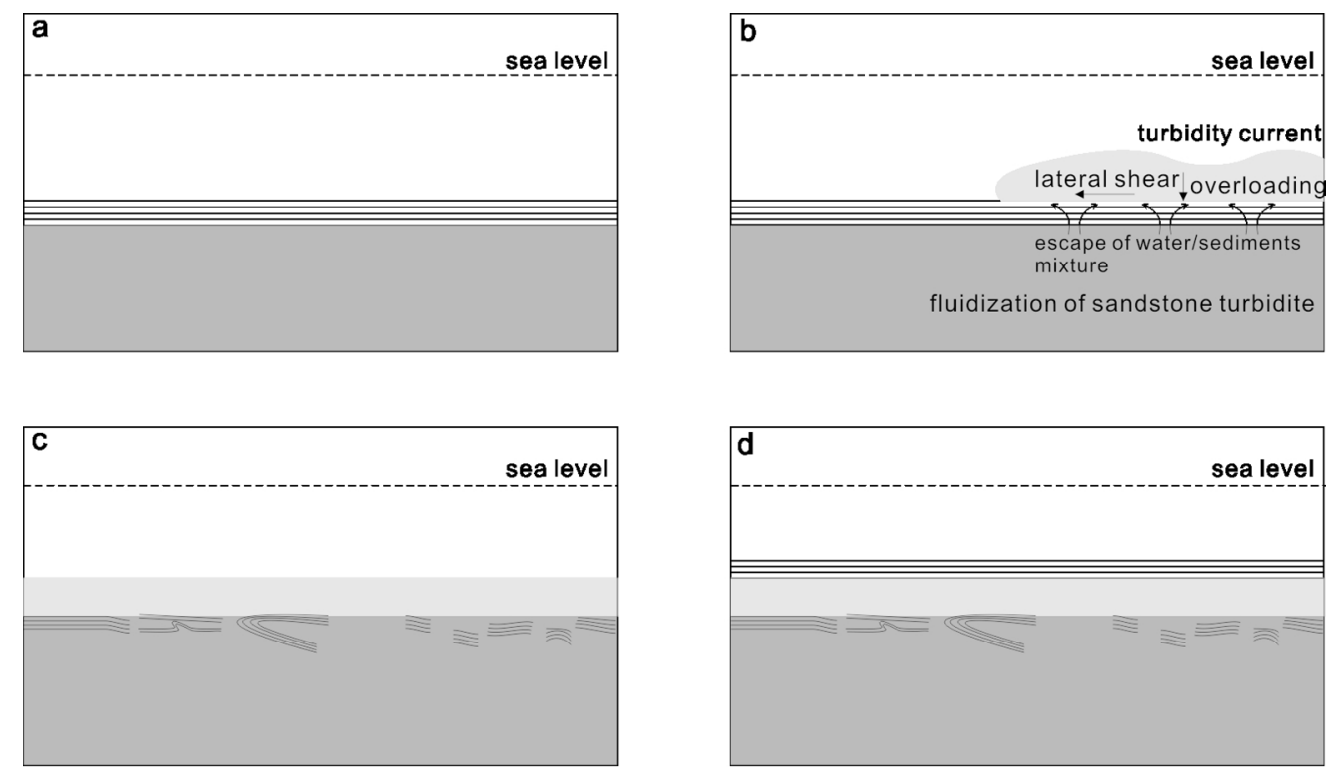

Fig. 8. Schematic model showing the genesis of the rip-up clasts. (a) deposition of a turbidite on a turbidite substratum. (b) escape of water/sediment mixtures; (c) rip-up clasts form in the liquefied sediment due to the erosional power and lateral shear exerted by the sand-rich lower part of the turbidity current. (d) deposition of the fine-grained upper part of the turbidite, preserving the rip-up clasts.

$134 \times 77 \mathrm{~mm}(300 \times 300$ DPI $)$ 